\title{
Effect of Cr Content on the Compression Properties and Abrasive Wear Behavior of the High-Volume Fraction $\left(\mathrm{TiC}-\mathrm{TiB}_{2}\right) / \mathrm{Cu}$ Composites
}

\author{
Feng Qiu $\cdot$ Yue Han $\cdot$ Ai Cheng $\cdot$ Jianbang Lu $\cdot$ Qichuan Jiang
}

Received: 18 April 2014/Revised: 24 July 2014/Published online: 9 October 2014

(C) The Chinese Society for Metals and Springer-Verlag Berlin Heidelberg 2014

\begin{abstract}
The $\left(\mathrm{TiC}-\mathrm{TiB}_{2}\right) / \mathrm{Cu}$ composites with $50 \mathrm{vol} \% \mathrm{TiC}-\mathrm{TiB}_{2}$ ceramic particles were successfully fabricated by the combustion synthesis and hot press consolidation in a $\mathrm{Cu}-\mathrm{Ti}-\mathrm{B}_{4} \mathrm{C}-\mathrm{Cr}$ system. The effects of the $\mathrm{Cr}$ content on the microstructures, hardness, compression properties, and abrasive wear behaviors of the composites were investigated. The final products consist of only $\mathrm{Cu}, \mathrm{TiC}$, and $\mathrm{TiB}_{2}$ phases, and the ceramic particles are distributed uniformly in these composites. The size of the ceramic particles decreases with $\mathrm{Cr}$ addition. As the $\mathrm{Cr}$ content increases, the yield strength, ultimate compression strength, microhardness, and abrasive wear resistance of the composites increase, and the fracture strain decreases.
\end{abstract}

KEY WORDS: Metal matrix composites; Powder metallurgy; Combustion synthesis; Abrasive wear

\section{Introduction}

In recent years, the copper has been widely used in industrial applications due to its high electrical and thermal conductivities, low cost (compared with $\mathrm{Ag}$ and $\mathrm{Au}$ ), and ease of fabrication. However, the relatively low hardness, low strength, and poor wear resistance limit its extensive applications [1-4]. These shortcomings could be avoided by the incorporation of ceramics into the copper matrix. Besides the $\mathrm{SiC}$ and $\mathrm{Al}_{2} \mathrm{O}_{3}$ ceramics, the $\mathrm{TiC}$ and $\mathrm{TiB}_{2}$ ceramics are commonly used as reinforcements in the $\mathrm{Cu}$ matrix composites [5-8]. Moreover, the $\mathrm{TiC}$ and $\mathrm{TiB}_{2}$ ceramic particles reinforced $\mathrm{Cu}$ matrix composites could be fabricated by the in situ method. While the composites with the monolithic ceramic particles exhibit relatively high

Available online at http://link.springer.com/journal/40195

F. Qiu · Y. Han · A. Cheng · J. Lu · Q. Jiang $(\bowtie)$

Key Laboratory of Automobile Materials, Ministry of Education,

Department of Materials Science and Engineering, Jilin

University, Changchun 130025, China

e-mail: jqc@jlu.edu.cn hardness, high wear resistance, and superior elevated temperature strength, the composites containing two-phase ceramic particles are believed to exhibit more superior properties $[9,10]$.

As known, the two-phase $\mathrm{TiC}-\mathrm{TiB}_{2}$ ceramic composite has higher wear resistance, mechanical and electrical properties compared with the monolithic $\mathrm{TiC}$ or $\mathrm{TiB}_{2}[11-$ 13]. In addition, minor additions should strongly influence the microstructures and mechanical properties of composites by combustion synthesis and hot press consolidation. However, few of systematic investigations of the effects of $\mathrm{Cr}$ addition on the combustion synthesis of $\left(\mathrm{TiC}-\mathrm{TiB}_{2}\right) / \mathrm{Cu}$ from a $\mathrm{Cu}-\mathrm{Ti}-\mathrm{B}_{4} \mathrm{C}-\mathrm{Cr}$ system have been carried out so far.

A number of fabrication methods have developed for the copper matrix composites, such as powder metallurgy technique [2, 3, 14-16], infrared infiltration technique [1], and pressureless infiltration [17]. Moreover, the combustion synthesis combined with hot press consolidation is another in situ method for producing the copper matrix composites with the advantages of the finer sizes and the more uniform dispersion of the synthesized ceramic particles, as well as the stronger interfacial bonding between the matrix and the reinforcements, which could lead to the 
good mechanical properties and high wear resistance of the composites [18-21].

Therefore, in this study, the $\mathrm{Cu}$ matrix composites reinforced with 50 vol\% $\mathrm{TiC}-\mathrm{TiB}_{2}$ ceramic particles were fabricated by the in situ method of the combustion synthesis combined with hot press consolidation in the $\mathrm{Cu}-\mathrm{Ti}-$ $\mathrm{B}_{4} \mathrm{C}-\mathrm{Cr}$ system, and the effect of the $\mathrm{Cr}$ content on the microstructures, compression properties, and abrasive wear behavior of the composites was investigated in detail.

\section{Experimental}

The raw materials used were commercial copper powders (99.7\% purity, $\sim 47 \mu \mathrm{m}$ in diameter), titanium powders (99.5\% purity, $\sim 25 \mu \mathrm{m}$ in diameter), $\mathrm{B}_{4} \mathrm{C}$ powders $(98 \%$ purity, $\sim 3.5 \mu \mathrm{m}$ in diameter), and $\mathrm{Cr}$ powders (99\% purity, $\sim 47 \mu \mathrm{m}$ in diameter). The theoretical molar ratio of $\mathrm{TiC}: \mathrm{TiB}_{2}$ in the composites was predetermined to be 1:2. Elemental powder blends corresponding to $50 \mathrm{vol} \%$ (TiC$\left.\mathrm{TiB}_{2}\right) / \mathrm{Cu}$ with $0,3,5$, and $7 \mathrm{wt} \% \mathrm{Cr}$ addition were mixed sufficiently by ball milling for $8 \mathrm{~h}$. After that, the mixtures were cold pressed into cylindrical samples $28 \mathrm{~mm}$ in diameter and $40 \mathrm{~mm}$ in height under a pressure of $42 \mathrm{MPa}$, and then the sample was put in a self-made vacuum thermal explosion furnace. The heating rate of the furnace was about $30 \mathrm{~K} / \mathrm{min}$ and the temperature near the center of the compact was measured by K-type thermocouple. When the detected temperature rose suddenly, indicating that the sample had been ignited, then the sample was quickly pressed by employing a pressure of $\sim 40 \mathrm{MPa}$ for a $10 \mathrm{~s}$ duration, and then the sample was cooled down to room temperature.

The phase constituents of the products were investigated by X-ray diffraction (XRD, Moldel D/Max 2500PC Riga$\mathrm{ku}$, Japan) with $\mathrm{Cu} K_{\alpha}$ radiation. The microstructure was investigated by scanning electron microscopy (SEM, Moldel Evo18 Carl Zeiss, Germany). Cylindrical samples with a diameter of $3 \mathrm{~mm}$ and a height of $6 \mathrm{~mm}$ were used for the compression tests, and the parallel loading surfaces were polished. The uniaxial compression tests were carried out using the servo-hydraulic materials testing system (MTS, MTS 810, USA) at a strain rate of $1 \times 10^{-4} \mathrm{~s}^{-1}$. Microhardness of the composites was measured by a Vickers hardness tester (Moldel 1600-5122VD, USA) using a static load of $2 \mathrm{~N}$ and a dwell time of $15 \mathrm{~s}$.

Abrasive wear tests were carried out on a pin-on-disktype apparatus at room temperature. The composites were machined into the block samples with the dimensions of $4 \mathrm{~mm} \times 4 \mathrm{~mm} \times 15 \mathrm{~mm}$ and the $4 \mathrm{~mm} \times 4 \mathrm{~mm}$ faces were employed as the wear surfaces. The applied normal loads were 15,25 , and $35 \mathrm{~N}$ and the sliding distance was kept constant at $24.78 \mathrm{~m}$. The worn $\mathrm{Al}_{2} \mathrm{O}_{3}$ abrasive paper was substituted for a new one for every sliding distance of

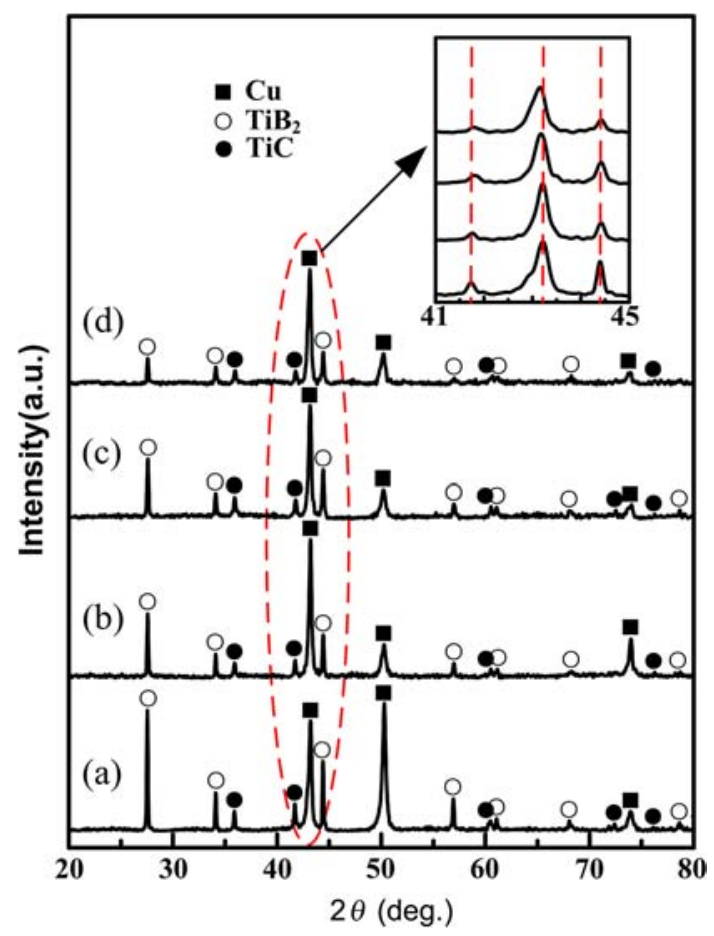

Fig. 1 XRD patterns of $50 \mathrm{vol} \%\left(\mathrm{TiC}-\mathrm{TiB}_{2}\right) / \mathrm{Cu}$ composites with different $\mathrm{Cr}$ additions: a 0 wt $\%$; b 3 wt $\%$; c 5 wt $\%$; d 7 wt $\%$

$8.26 \mathrm{~m}$, making sure that the samples would contact with the fresh abrasive particles. The abrasive wear rate of the composites is defined as the volume loss suffered per unit sliding distance, and the volume loss is obtained from the ratio of weight loss to the density of the composites. The weight loss was measured before and after the wear test using an electronic balance with a resolution of $0.1 \mathrm{mg}$, and the density of the composites was measured by Archimedes' method. The worn surfaces of the samples were observed by SEM.

\section{Results and Discussion}

\subsection{Phase Identification and Microstructures}

Figure 1 shows XRD patterns for the $50 \mathrm{vol} \%\left(\mathrm{TiC}-\mathrm{TiB}_{2}\right) /$ $\mathrm{Cu}$ composites with $0,3,5$, and $7 \mathrm{wt} \% \mathrm{Cr}$ additions. It can be seen that all the products consist of $\mathrm{Cu}, \mathrm{TiC}$, and $\mathrm{TiB}_{2}$ phases, without any intermediate phases, the phase constitutions of the composites are not changed with the addition of Cr. The inset in Fig. 1 shows that the peak position of the $\mathrm{Cu}$ (111) plane shifts to lower $2 \theta$ values, and the one of the $\mathrm{TiC}$ (200) plane shifts to higher $2 \theta$ values with the increase in the $\mathrm{Cr}$ content, implying the increases in the lattice constant of $\mathrm{Cu}$, and the decreases in the lattice constant of TiC. 

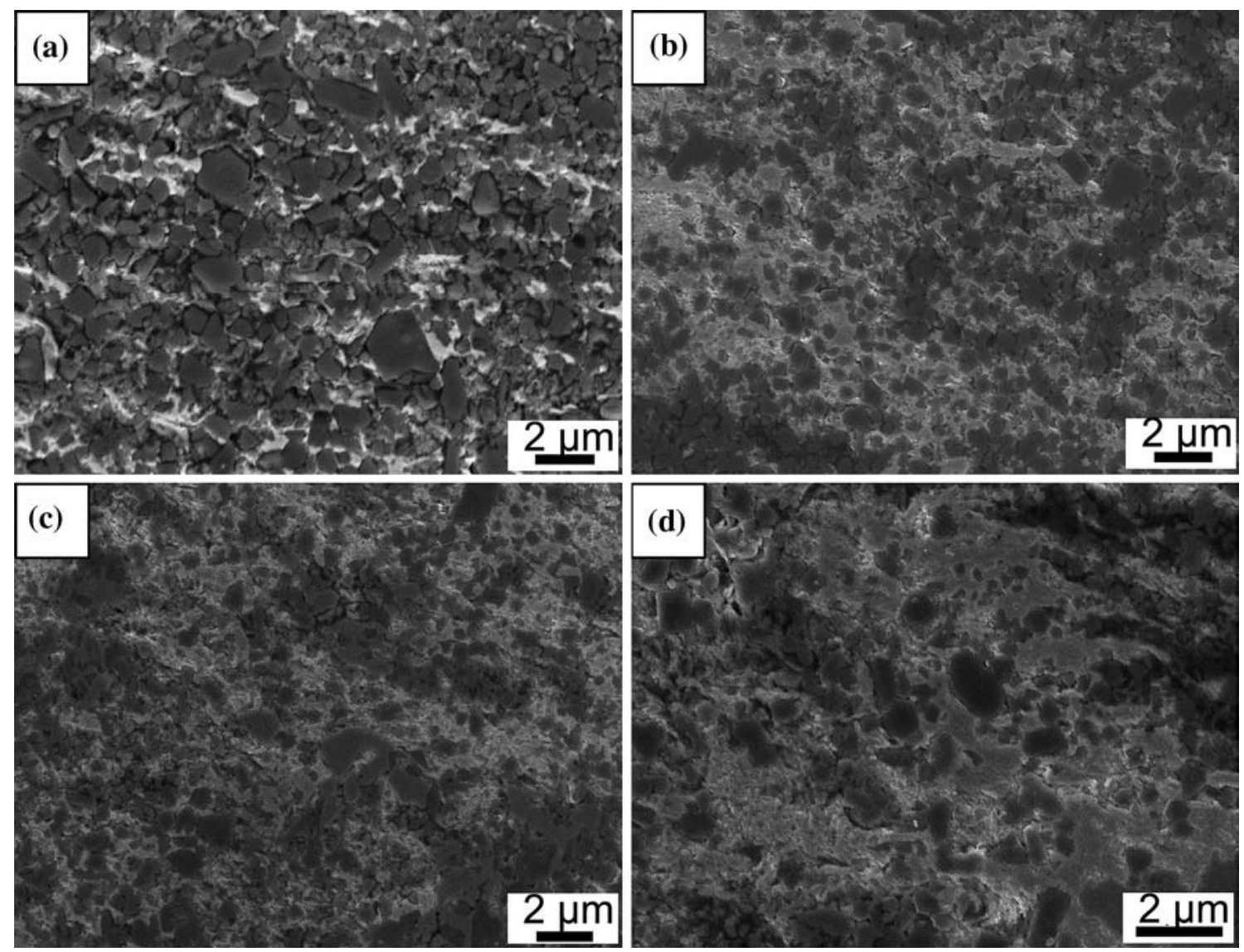

Fig. 2 SEM images of microstructures of 50 vol $\%\left(\mathrm{TiC}_{-} \mathrm{TiB}_{2}\right) / \mathrm{Cu}$ composites with different $\mathrm{Cr}$ contents: a 0 wt $\%$; b 3 wt $\%$; c 5 wt $\%$; d 7 wt $\%$

It is conjectured that $\mathrm{Cr}$ can occupy the positions of $\mathrm{Cu}$ in the $\mathrm{Cu}$ crystal lattice and the ones of $\mathrm{Ti}$ in the TiC crystal lattices. As a result, these lattices expand because the atomic radius of $\mathrm{Cr}(1.85 \mathrm{~nm})$ is larger than that of $\mathrm{Cu}$ $(1.57 \mathrm{~nm})$ in the $\mathrm{Cu}$ matrix, and these lattices deflate because the atomic radius of $\mathrm{Cr}(1.85 \mathrm{~nm})$ is smaller than that of $\mathrm{Ti}(2.0 \mathrm{~nm})$ in TiC. Thus, it can be deduced that the severe lattice distortion in the $\mathrm{Cu}$ matrix and $\mathrm{TiC}$ occurred. Meanwhile, the full half width of the peaks of TiC (200) plane and $\mathrm{TiB}_{2}$ (101) plane increases with increasing $\mathrm{Cr}$ addition. Hence, it is believed that the broad diffraction maxima (Fig. 1) can be attributed to the internal strain. As the $\mathrm{Cr}$ content increased, the internal strain increased and the sizes of the $\mathrm{TiC}$ and $\mathrm{TiB}_{2}$ particles decreased.

Figure 2 shows the SEM images of the 50 vol\% (TiC$\left.\mathrm{TiB}_{2}\right) / \mathrm{Cu}$ composites with $0,3,5$, and $7 \mathrm{wt} \% \mathrm{Cr}$ additions. The composites fabricated by the in situ method are dense. The synthesized spherical TiC and hexagonal plates shaped $\mathrm{TiB}_{2}$ particles are distributed uniformly in the copper matrix, and their sizes are nonuniform. The sizes of the $\mathrm{TiC}$ and $\mathrm{TiB}_{2}$ particles decreased from $\sim 2 \mu \mathrm{m}$ to smaller than $1 \mu \mathrm{m}$ as the $\mathrm{Cr}$ addition increased. It is in accord with increase in the full half width of the peaks of $\mathrm{TiC}(200)$ plane and $\mathrm{TiB}_{2}(101)$ plane with increasing $\mathrm{Cr}$ addition in XRD.
The size decreases of the $\mathrm{TiC}$ and $\mathrm{TiB}_{2}$ particles might be attributed to the decrease of the combustion temperature. As known, the growth of the ceramic particles is an exponential function of the combustion temperature [22], that is, the lower the combustion temperature is, the smaller the size of the ceramic particles is. Thus, the sizes of the ceramic particles decreased greatly with the $\mathrm{Cr}$ addition because only a portion of $\mathrm{Cr}$ participated in the reaction and more amount of heat was needed to melt increased $\mathrm{Cr}$.

\subsection{Compression Properties}

Figure 3 shows the compression engineering stress-strain curves of the $\left(\mathrm{TiC}-\mathrm{TiB}_{2}\right) / \mathrm{Cu}$ composites with different $\mathrm{Cr}$ contents. The mechanical properties and microhardness of the composites are summarized in Table 1. The yielding strength (YS), ultimate compression strength (UCS), and microhardness of the composites increase from $1003 \mathrm{MPa}$, $1252 \mathrm{MPa}$, and $404 \mathrm{HV}$ to $1315 \mathrm{MPa}, 1827 \mathrm{MPa}$, and $543 \mathrm{HV}$, respectively, with increasing $\mathrm{Cr}$ content from 0 to $7 \mathrm{wt} \%$, while the fracture strain $\left(\varepsilon_{\mathrm{f}}\right)$ decreases from $5.8 \%$ to $1.9 \%$. 


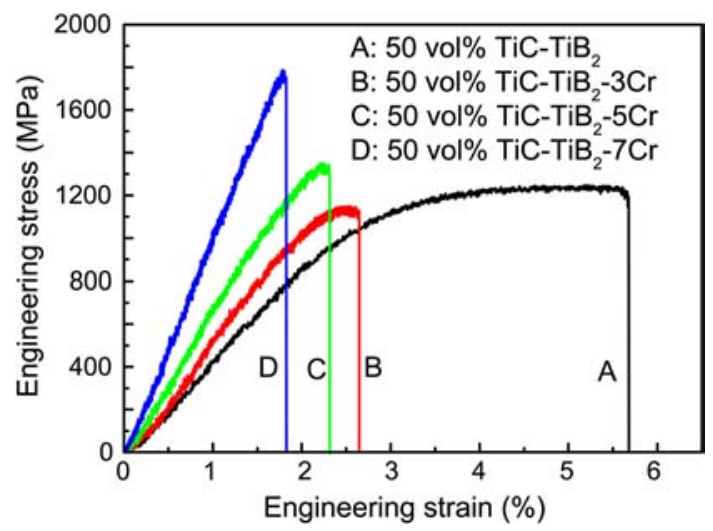

Fig. 3 Compression engineering stress-strain curves of $50 \mathrm{vol} \%$ $\left(\mathrm{TiC}-\mathrm{TiB}_{2}\right) / \mathrm{Cu}$ composites with different $\mathrm{Cr}$ contents

Table 1 Room-temperature compression properties and microhardness of $50 \mathrm{vol} \%\left(\mathrm{TiC}-\mathrm{TiB}_{2}\right) / \mathrm{Cu}$ composites with different $\mathrm{Cr}$ contents

\begin{tabular}{lllll}
\hline $\begin{array}{l}\text { Cr content } \\
(\mathrm{wt} \%)\end{array}$ & $\begin{array}{l}\sigma_{0.2} \\
(\mathrm{MPa})\end{array}$ & $\begin{array}{l}\sigma_{\mathrm{UCS}} \\
(\mathrm{MPa})\end{array}$ & $\varepsilon_{\mathrm{f}}(\%)$ & $\begin{array}{l}\text { Hardness } \\
(\mathrm{HV})\end{array}$ \\
\hline 0 & $1003_{-46}^{+33}$ & $1252_{-54}^{+30}$ & $5.8_{-0.2}^{+0.3}$ & $404 \pm 8$ \\
3 & $1113_{-43}^{+29}$ & $1161_{-48}^{+35}$ & $2.7_{-0.3}^{+0.2}$ & $436 \pm 8$ \\
5 & $1315_{-55}^{+46}$ & $1358_{-45}^{+51}$ & $2.3_{-0.1}^{+0.2}$ & $491 \pm 10$ \\
7 & - & $1827_{-52}^{+63}$ & $1.9_{-0.2}^{+0.1}$ & $543 \pm 10$ \\
\hline
\end{tabular}

The strength of the composites is determined by the strength of the reinforcement and matrix, and the interfacial bonding strength between the particles and the matrix. When the content of the $\mathrm{Cr}$ increases, the strength and hardness of the composites increase, which is due to the finer particles, the $\mathrm{Cr}$ solid solution in the $\mathrm{Cu}$ matrix and the $\mathrm{TiC}$, and the improvement of the interfacial bonding strength between the ceramic particles and the copper matrix. The finer ceramic particles could be a factor for improving the compression strength and hardness of the composites with the $\mathrm{Cr}$ addition. It is well known that better reinforcing effect and higher hardness can be achieved in the composites with smaller ceramic particles. Another reason of composite strengthening is $\mathrm{Cr}$ solid solution in the TiC, which could result in the large lattice distortion and enhance strength and hardness of the TiC. Besides, the enhanced strength of the matrix is the other important factor. As known, the dissolution of $\mathrm{Cr}$ into the $\mathrm{Cu}$ matrix can increase its strength and hardness by solid solution strengthening. Lastly, the wettability between these ceramic particles and the $\mathrm{Cu}$ matrix is improved by the addition of $\mathrm{Cr}$. It would enhance the interfacial bonding strength between the ceramic particles and the copper matrix.

Figure 4 shows the SEM images of the compression fracture surfaces of the $\left(\mathrm{TiC}-\mathrm{TiB}_{2}\right) / \mathrm{Cu}$ composites with different $\mathrm{Cr}$ contents. As indicated, all the ceramic particles are well enwrapped by the copper matrix, indicating that the bonding between the particles and the copper is quite satisfied. In this case, the compressive strength of the composites is mainly controlled by the finer ceramic particles, the $\mathrm{Cr}$ solid solution in the $\mathrm{Cu}$ matrix, and the improvement of bonding strength between these ceramics and the copper matrix. Thus, the increase of the $\mathrm{Cr}$ content will reduce the sizes of the $\mathrm{TiC}$ and $\mathrm{TiB}_{2}$ particles in the composites, enhance solid solution strengthening in the $\mathrm{Cu}$ matrix and $\mathrm{TiC}$, and enhance the bonding strength between the $\mathrm{TiC} / \mathrm{TiB}_{2}$ ceramics and the copper matrix. However, with too much solid solution of $\mathrm{Cr}$ in the composites, the composite matrix would be split due to the severe lattice distortion and then the ductility of the composites decreases with the $\mathrm{Cr}$ addition.

\subsection{Abrasive Wear Properties}

Figure 5 shows the variation of wear rate with the applied loads for the pure copper and the composites tested against the $\mathrm{Al}_{2} \mathrm{O}_{3}$ abrasive particles of $45 \mu \mathrm{m}$. It is apparent that the pure copper experiences an extremely high wear rate than the composites. This indicates that the $\mathrm{Al}_{2} \mathrm{O}_{3}$ abrasives can penetrate easily into the soft copper during sliding, resulting in excessive material removal from the surface, and the wear rate of the composites reduced as the $\mathrm{Cr}$ content increased. This can also be confirmed by the worn surfaces of the pure copper and the composites, as shown in Fig. 6. As it can be seen from Fig. $6 \mathrm{a}$, the $\mathrm{Al}_{2} \mathrm{O}_{3}$ particles deeply penetrated into the pure copper, which could lead to the extensive deformation and fracture in the subsurface region of the pure copper.

The worn surfaces of the $\left(\mathrm{TiC}-\mathrm{TiB}_{2}\right) / \mathrm{Cu}$ composites with different $\mathrm{Cr}$ contents are shown in Fig. 6b-f, which are relatively smoother than that of the pure copper. Since the ceramic particles are much harder than the copper matrix, higher wear resistance can be obtained. Moreover, with the increase in the $\mathrm{Cr}$ content, the worn surfaces of the composites become smoother. The much harder and finer ceramic particles can act as barriers that can protect the copper matrix from the plastic deformation and removal, leading to the slighter micro-plowing and lower wear rate of the composites. Besides, the dissolution of $\mathrm{Cr}$ into the $\mathrm{Cu}$ matrix can increase its strength and hardness by solid solution strengthening. Therefore, the abrasive wear resistance of the composites is better than that of the pure copper. As the $\mathrm{Cr}$ content increases, the resistance to the penetration of the abrasive particles is increased, leading to the better abrasive wear resistance.

When the applied loads increase from 15 to $35 \mathrm{~N}$, the worn surface of the $50 \mathrm{vol} \%\left(\mathrm{TiC}-\mathrm{TiB}_{2}\right) / \mathrm{Cu}$ composite with $7 \mathrm{wt} \% \mathrm{Cr}$ addition become rougher, as shown in 

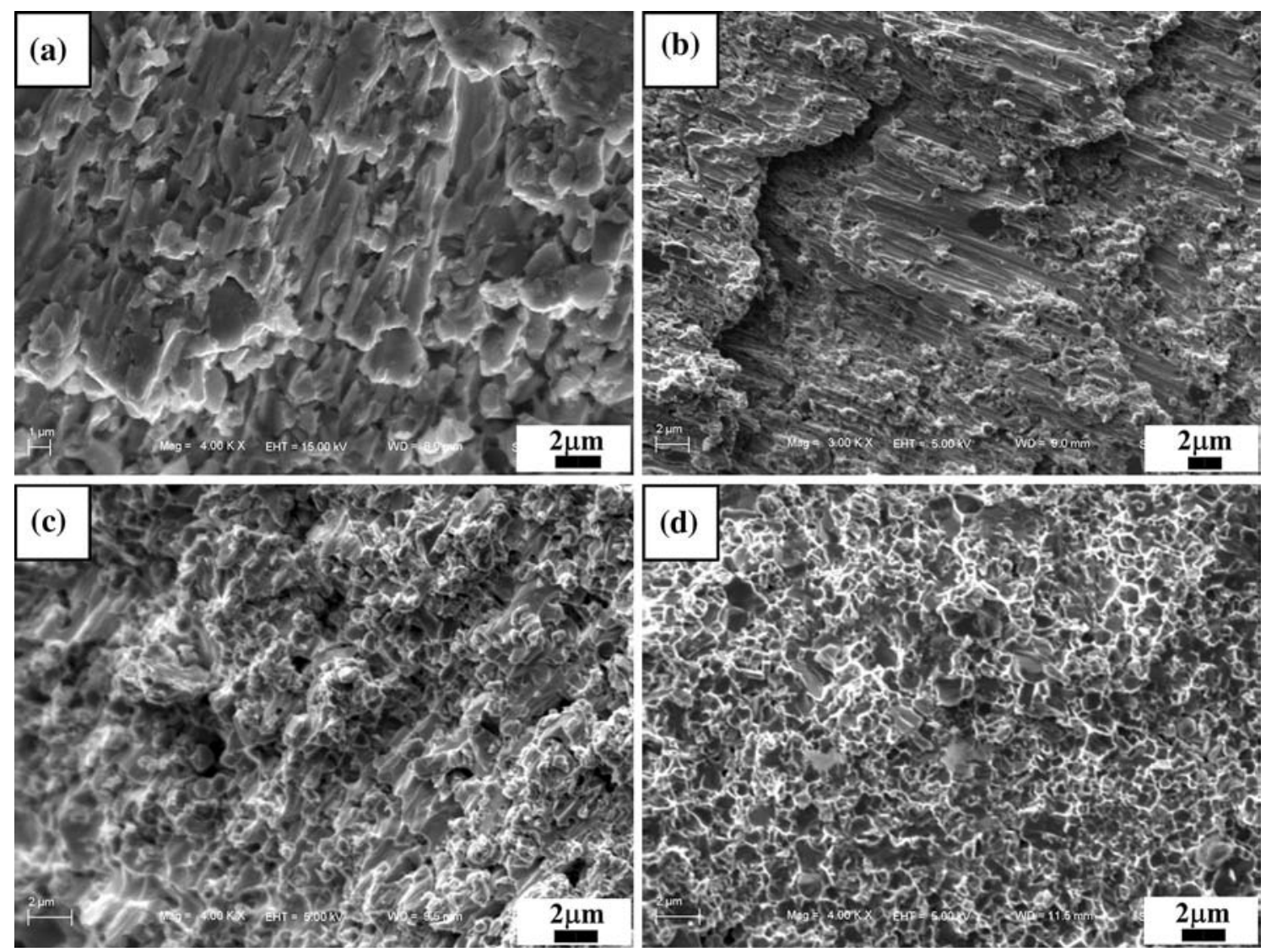

Fig. 4 SEM images of the compression fractured surfaces for $50 \mathrm{vol} \%\left(\mathrm{TiC}-\mathrm{TiB}_{2}\right) / \mathrm{Cu}$ composites with different $\mathrm{Cr}$ contents: a 0 wt\%; b 3 wt $\%$; 5 wt $\%$; d 7 wt $\%$

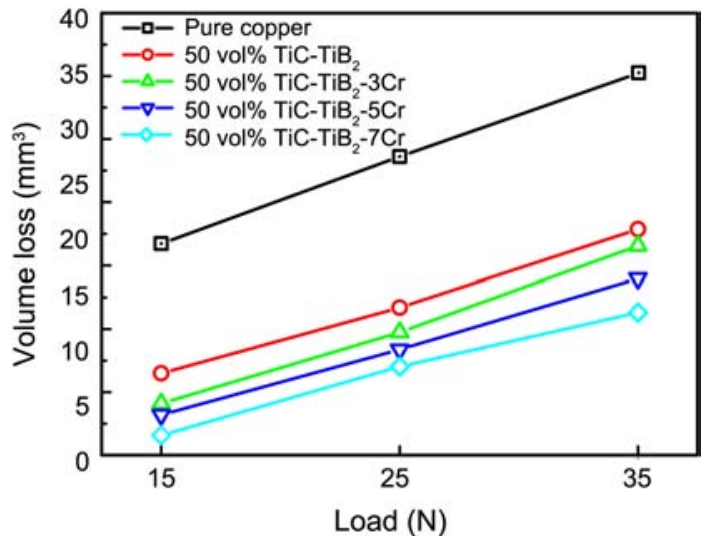

Fig. 5 Wear rate versus applied load under the counterface of $45 \mu \mathrm{m}$ $\mathrm{Al}_{2} \mathrm{O}_{3}$ abrasive particles for the pure copper and the $\left(\mathrm{TiC}-\mathrm{TiB}_{2}\right) / \mathrm{Cu}$ composites with different $\mathrm{Cr}$ contents

Fig. 6e, f. The $\mathrm{Al}_{2} \mathrm{O}_{3}$ abrasives will penetrate deeper as the applied load increases and subsequent sliding results in high wear rate in the composite. When the applied load is relatively large $(35 \mathrm{~N})$, these smaller $\mathrm{TiC}$ and $\mathrm{TiB}_{2}$ ceramic particles are easily removed from the copper matrix, corresponding to the bigger depth of the furrow. The abrasive particles of $45 \mu \mathrm{m}$ can easily penetrate into the composite and result in a serious wear of the composites. It is worth mentioning that the abrasive wear resistance of the 50 vol\% $\left(\mathrm{TiC}-\mathrm{TiB}_{2}\right) / \mathrm{Cu}$ composite with $7 \mathrm{wt} \% \mathrm{Cr}$ addition was improved by $138 \%$ and $39 \%$, respectively, compared with pure copper and $50 \mathrm{vol} \%\left(\mathrm{TiC}-\mathrm{TiB}_{2}\right) / \mathrm{Cu}$ composite when the applied load is $15 \mathrm{~N}$.

As mentioned above, the abrasive wear of the (TiC$\left.\mathrm{TiB}_{2}\right) / \mathrm{Cu}$ composites consists of two stages. First, the $\mathrm{Al}_{2} \mathrm{O}_{3}$ abrasive particles penetrate into the soft copper matrix and cut it, leading to excessive copper removal from the composites. Meanwhile, the $\mathrm{Al}_{2} \mathrm{O}_{3}$ abrasives also have an impact on the $\mathrm{TiC}$ and $\mathrm{TiB}_{2}$ ceramic particles, resulting in the blunting of the $\mathrm{Al}_{2} \mathrm{O}_{3}$ abrasives. In the second stage, the $\mathrm{TiC}$ and $\mathrm{TiB}_{2}$ ceramic particles are exposed from the copper matrix and they act as a barrier to the micro-cutting action of the abrasives, inducing the decrease in the cutting efficiency of the $\mathrm{Al}_{2} \mathrm{O}_{3}$ abrasives and the consequent wear rate of the composites. When the exposed $\mathrm{TiC}$ and $\mathrm{TiB}_{2}$ ceramic particles are removed from the worn surface of the composites, the $\mathrm{Al}_{2} \mathrm{O}_{3}$ abrasives will impact the copper matrix and the $\mathrm{TiC}-\mathrm{TiB}_{2}$ ceramic particles simultaneously again. 

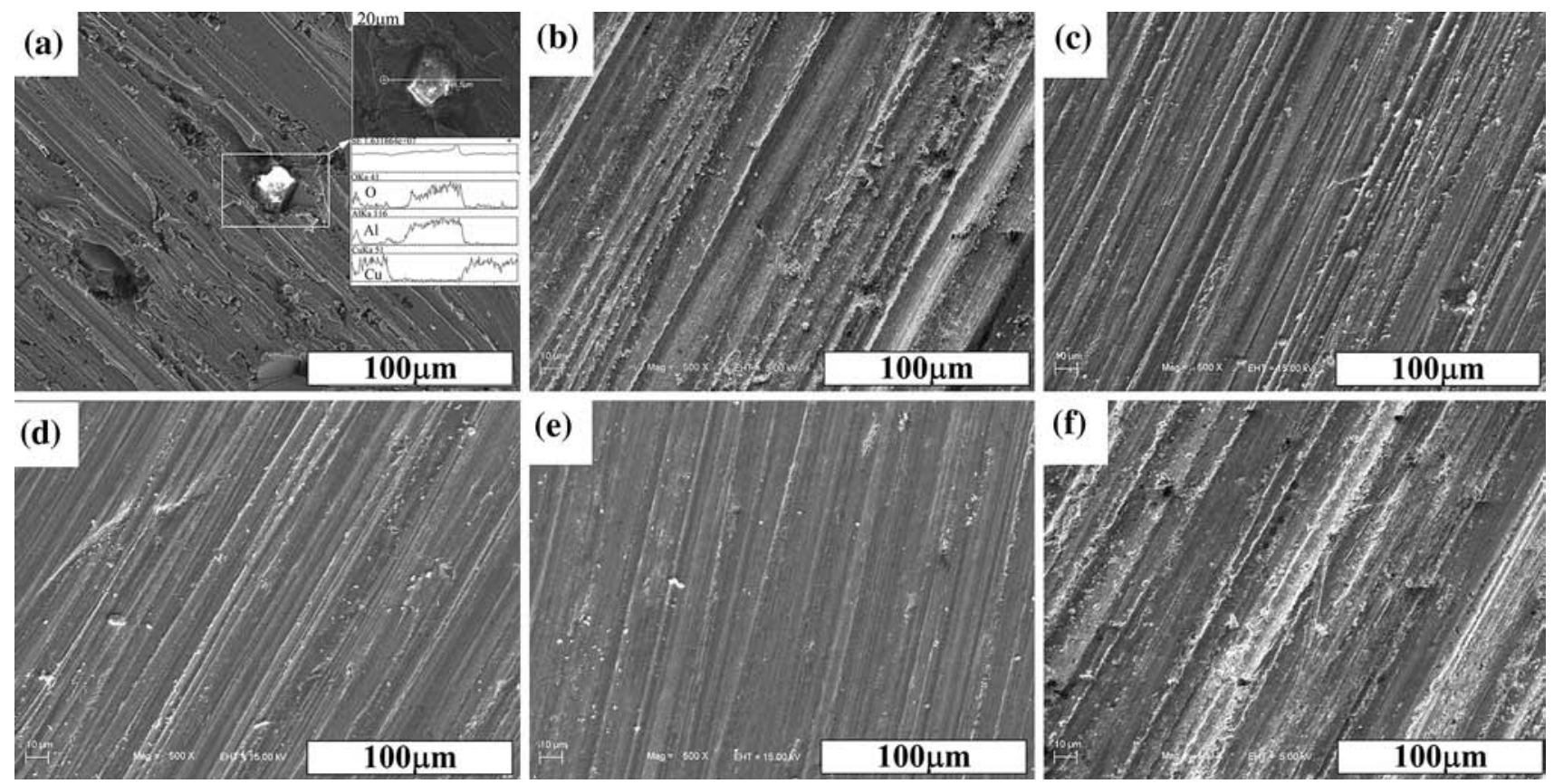

Fig. 6 Worn surfaces of the pure copper a, 50 vol\% $\left(\mathrm{TiC}-\mathrm{TiB}_{2}\right) / \mathrm{Cu}$ composites without $\mathrm{Cr}$ addition b, with 3 wt $\% \mathrm{Cr} \mathbf{c}, 5 \mathrm{wt} \% \mathrm{Cr} \mathbf{d}, 7$ wt $\% \mathrm{Cr}$ e, $\mathbf{f}$ additions. The applied load is $15 \mathrm{~N}$ for $\mathbf{a}-\mathbf{e}$, and the applied load is $35 \mathrm{~N}$ for $\mathbf{f}$

\section{Conclusions}

(1) $50 \mathrm{vol} \%\left(\mathrm{TiC}-\mathrm{TiB}_{2}\right) / \mathrm{Cu}$ composites with different $\mathrm{Cr}$ additions were successfully fabricated by the combustion synthesis and hot press consolidation in a $\mathrm{Cu}-$ $\mathrm{Ti}-\mathrm{B}_{4} \mathrm{C}-\mathrm{Cr}$ system. The ceramic particles are distributed uniformly in the composites and the ceramic particle sizes decrease from $2 \mu \mathrm{m}$ to smaller than $1 \mu \mathrm{m}$ with increasing the $\mathrm{Cr}$ content.

(2) The yield strength, ultimate compression strength, hardness, and wear resistance of the composites increase as the $\mathrm{Cr}$ content increases. The composite with $7 \mathrm{wt} \% \mathrm{Cr}$ possesses the highest hardness $(543 \mathrm{HV})$ and the superior compression strength (1827 MPa), resulting in an overall increase by $35 \%$ and $45 \%$, compared with those of the $50 \mathrm{vol} \%$ (TiC$\left.\mathrm{TiB}_{2}\right) / \mathrm{Cu}$ composites without $\mathrm{Cr}$ addition, respectively.

(3) The enhancement of the hardness, compression strength, and wear resistance of the composites with the increase of the $\mathrm{Cr}$ addition is mainly due to the refinement of the ceramics, and the solid solution of $\mathrm{Cr}$ in the $\mathrm{Cu}$ matrix and $\mathrm{TiC}$.

Acknowledgments This work was financially supported by the National Natural Science Foundation of China (Nos. 51171071, 50971065 and No. 50531030), National Basic Research Program of China No. 2012CB619600), the Research Fund for the Doctoral Program of Higher Education of China (No. 20130061110037) and the Project 985-High Performance Materials of Jilin University.

\section{References}

[1] P.K. Deshpande, R.Y. Lin, Mater. Sci. Eng. A 418, 137 (2006)

[2] S.C. Tjong, K.C. Lau, Mater. Lett. 43, 274 (2000)

[3] S.C. Tjong, K.C. Lau, Mater. Sci. Eng. A 282, 183 (2000)

[4] N. Zarrinfar, A.R. Kennedy, P.H. Shipway, Scr. Mater. 50, 949 (2004)

[5] D.W. Lee, G.H. Ha, B.K. Kim, Scr. Mater. 44, 2137 (2001)

[6] J.P. Tu, N.Y. Wang, Y.Z. Yang, W.X. Qi, F. Liu, X.B. Zhang, H.M. Lu, M.S. Liu, Mater. Lett. 52, 448 (2002)

[7] F. Shehata, A. Fathy, M. Abdelhameed, S.F. Moustafa, Mater. Des. 30, 2756 (2009)

[8] S.Y. Chang, S.J. Lin, Scr. Mater. 35, 225 (1996)

[9] W. Zhang, N. Travitzky, P. Greil, J. Am. Ceram. Soc. 91, 3117 (2008)

[10] F. Olevsky, P. Mogilevsky, E.Y. Gutmanas, I. Gotman, Metall. Mater. Trans. A 27, 2071 (1996)

[11] D. Vallauri, F.A. Deorsola, Mater. Res. Bull. 44, 1528 (2009)

[12] B.S. Du, S.R. Paital, N.B. Dahotre, Scr. Mater. 59, 1147 (2008)

[13] J.J. Liu, Z.D. Liu, Mater. Lett. 64, 684 (2010)

[14] F. Akhtara, S.J. Askaria, K.A. Shaha, X.L. Du, S.J. Guo, Mater. Charact. 60, 327 (2009)

[15] L. Xia, B.B. Jia, J. Zeng, J.C. Xu, Mater. Charact. 60, 363 (2009)

[16] S.R. Dong, J.P. Tu, X.B. Zhang, Mater. Sci. Eng. A 313, 83 (2001)

[17] L. Zhang, X.B. He, X.H. Qu, B.H. Duan, X. Lu, M.L. Qin, Wear 265, 1848 (2008)

[18] F. Akhtar, J. Alloys Compd. 459, 491 (2008)

[19] H.Y. Wang, L. Huang, Q.C. Jiang, Mater. Sci. Eng. A 407, 98 (2005)

[20] B.M. Chen, Q.L. Bi, J. Yang, Y.Q. Xia, J.C. Hao, Mater. Sci. Eng. A 491, 315 (2008)

[21] Y.H. Liang, H.Y. Wang, Y.F. Yang, R.Y. Zhao, Q.C. Jiang, J. Alloys Compd. 462, 113 (2008)

[22] Y. Choi, S.W. Rhee, J. Mater. Sci. 28, 6669 (1993) 